\author{
Ivan Tolić* \\ Vanja Šimunec ${ }^{* *}$ \\ Dijana Vuković***
}

\title{
VIDEO GAME CONSUMER PROFILES
}

\section{Summary}

The video game development path is full of drastic changes. The growth and strengthening of technology and the growth of innovation in the technology sector have inevitably led to the growth of this industry, which is nowadays achieving unexpected, enviable results. The basic human need for entertainment and socializing contributes to the popularity of video games. Today, video games are played by people of all ages and genders, and the most common reasons for playing video games are fun, socializing, learning, and reducing stress, but video games also provide interactive entertainment, unlike books, movies or theatre performances. The popularity of video games is witnessed by numerous communities on social networks through which professional gamers share their experiences, tips and video game reviews, and there are statistics that support this popularity and growth. The features offered by the video game industry do not need to be particularly emphasized because the results, statistics and enthusiastic players speak for themselves. This paper deals with the demographics and behaviour of consumers playing video games. The aim is to identify the main features of the user, video game players, and to identify and determine user habits and trends affecting the users. The consumer is a social and cultural being. At the same time, he is an individual for himself, a member of a family, a member of a group or a certain class or class in society, a representative of a particular nation, race, religion, nationality of a particular country, etc. The consumer is a person who has the money (assets) and a will to buy the goods or a service. In this paper, the above consumer definitions will be brought in correlation with the video game market, with an industry that encompasses various forms of modern entertainment. It is shown that technology and new modes of entertainment are present among all, and that we need to adjust the time we live in. Playing some kind of video games has become a normal activity of any normal, modern individual.

Key words: consumer behaviour, video games, gamer, gaming, influencer, marketing, social networks, esport, market, industry, user, player

Assist. prof. Ivan Tolić, Ph.D., Zagreb School of Business, ivan2.tolic@gmail.com

**Vanja Šimunec, M. Econ, University North, vasimunec@unin.hr

*** Assist. prof. Dijana Vuković, Ph.D., University North, dvukovic@unin.hr 


\section{Introduction}

A consumer is a social and cultural being. He is at the same time an individual for himself, a family member, a member of a group or a certain social class, a representative of a particular nation, race, religion, citizen of a particular country, etc. A consumer is the person who owns the money (funds) and the will to buy products and services. A consumer's behavior can certainly be unpredictable and deceptive, especially if we are talking about new generation industries and markets, the 21st century markets. One such market is the video games market with its users, consumers. The video game market is part of the entertainment industry, an industry that is moving the world today and changing it through information and telecommunications technology. Due to their specificity, video games are unique in their interaction with their users (consumers), and this interaction differs from person to person due to their individual approach, habits, behaviors, and factors that influence how users perceive video games and the effects and benefits that these videos have on users, or consumers. Nowadays, video games are a global phenomenon in any shape or form and are widely accepted even by older generations, slowly becoming an integral part of life. Younger generations just cannot imagine life without this kind of technology and fun any longer. The video game industry has progressed so much over the last few years that it is hard to imagine that the industry nowadays has to deal with difficult preconceptions that continue to rule the media and public space.

\section{Video games}

The world is constantly changing. It is time of sudden, diverse, and profound changes, and we live in an age where technology is often the leader of such great cultural transitions and changes. Not so long ago, most people were content to entertain themselves passively, while today many are not content to just sit on the couch and imitate the audience. Nowadays, many insist on a way more active role. The creation of games is the basic urge of the Homo sapiens. The ancient Greeks, Vikings, and most likely even our ancient ancestors from the caves had some sort of rule-based games (Egenfeldt-Nielsen et al., 2008: 1).

Games and playing is very important for young people as it can prepare them for the future. A person learns through games about the world and culture. Since the ancient times, games have been one of the basic features of human life, as well as one of the most significant children's activity. Through games, children learn to communicate, gain confidence of their own strengths, and create some positive images of themselves. Learning about social behavior and friendships, and learning that the rules agreed upon and boundaries must be respected are important factors for every 
child, even an adult. Playing is a special part of a person's life, and it is therefore important to pay as much attention to it as possible. Although the first associations with the words „play" or "playing” may be „hide and seek” or „sorry," this paper will show and prove that the most popular game nowadays are video games. There are three main reasons why video games should be taken seriously and why they should be played with an importance: the size of the video game industry, the popularity of video games, and the fact that video games are an example of interaction between a human and computer (Esposito, 2005: 1).

Some basic set of characteristics that must be possessed in order to be called and considered a video game is that there is some kind of gameplay, and this is a set of framed and specific rules where the person who plays can perform a group of activities through interaction. Such group activities usually must have some goals, so this is one of the main features of video games. Furthermore, video games are virtual, meaning they are displayed on small screens of our devices, ranging from cell phones, to computers or various types of consoles. In short, video games also have this interactive side, and are accompanied by different rules and frameworks that direct and control the player. Important aspects of video games are the stories that follow such gameplay, even music that is produced and recorded specifically for video game purposes.

\subsection{Video games culture}

Video game culture is a new media subculture formed by video games. Video games have gained popularity in recent years and thus have developed a significant influence on the popular culture. The video games culture has also evolved over time with the internet culture, as well as the increasing popularity of mobile games. Many people who play video games identify themselves as gamers, which can mean anything from someone who enjoys games to someone who is passionate about it and plays them very often. As video games are becoming more social with different multiplayer (more than one player is playing a game at the same time) and online features, these players, i.e. gamers, are forced to get introduced to and use bigger amount of social networks available in the world nowadays.

Playing video games and games can be fun, as well as a competition known as electronic sport (esport), which is becoming increasingly popular and accepted by the general public. Nowadays, video games can be seen on social networks, in politics, on television, in movies, or on music channels. The video game culture is characterized by questions such as „who is playing,” „what are they playing,” and „how are they playing" (Shaw, 2010: 414). Seeing how video games affect other video games is not something that would be a problem for many people to understand. However, the following point was not often discussed until recent years: the idea that video games 
have a significant impact on culture and society at some broader level, just like some kind of art. The question is: Why couldn't video games have such an impact as the rock music, for example? An interesting fact is that almost as long as there has been modern rock music, there have also been video games. Rock music has been around for decades, while video games still seem like some kind of a weird cultural anomaly. All the articles that have been written and all the research that has been done in the last few decades state that the amount of money that video games generate is greater than the biggest movie titles, but still the perception about it cannot be changed. Something strange has happened with video games. Something that kept them from gaining the same cultural influence for decades as the film and music industries did.

\subsection{Global video games market analysis}

It has taken more than 35 years for the global video game market to reach $\$ 35$ billion in 2007. Interestingly, 2007 was the year when the iPhone was introduced, one of the pinnacles of today's modern smartphones. Since then, the video game market has grown by an additional $\$ 100$ billion by 2018. (NewZoo, 2018: 3). As stated earlier, the explosion and growth of smartphones was a key factor of the growth of the video game market, mostly through market revenue and customer engagement. Finally, it was the consumer who determined the pace of these changes. No other form of entertainment or media gives as much power to the consumer as video games. Nowadays, games not only empower people to participate actively, but they also allow them to enjoy their passion for playing in a way that suits every mood, interest, lifestyle, location, and even budget. The global gaming industry has evolved again in order to maximize consumer engagement and revenue growth globally. The time has come to stop with the old terminology and rethink how we segment consumers based on behavior diversity and preferences.

In this highly growing and progressive industry, it is very difficult to keep up to date with predictions and forecasts, because all annual growth forecasts of this industry have been exceeded. It is important to note that this market consists of several gaming segments: PC, or. personal computer (content downloaded from the web, content that can be played via a web browser), console (PlayStation, Xbox), smartphone, and tablets.

Knowing that this market was worth only $\$ 35$ billion in 2007, its growth of over $\$ 100$ billion in just 10 years is fascinating. Last year, video game industry revenue totaled about $\$ 137$ billion, while the latest market projection in 2021 states that the entire market will be worth a dizzying \$ 180 billion (NewZoo, 2018: 14). Figure 1 shows that most of this revenue belongs to the smartphone market, which nowadays accounts for the biggest arto $f$ the video game industry due to the smartphone explosion that has taken place in recent years. The console and PC markets are mostly of 
the same value, while the least revenue is generated in the tablet market, only $10 \%$ of the total revenue. Figure 2 shows the global status of the video game industry, focusing on what are the largest global markets and how much they are worth.

Figure 1. Segmented display of the video games global market revenue

$\square$ downloaded/boxed PC
$\square$ browser PC
$\square$ console
$\square$ tablet
$\square$ (smart)phone

Source: https://cdn2.hubspot.net/hubfs/700740/Reports/Newzoo_2018_Global_Games Market_Report_Light.pdf.

Figure 2. The biggest global video games market, 2018

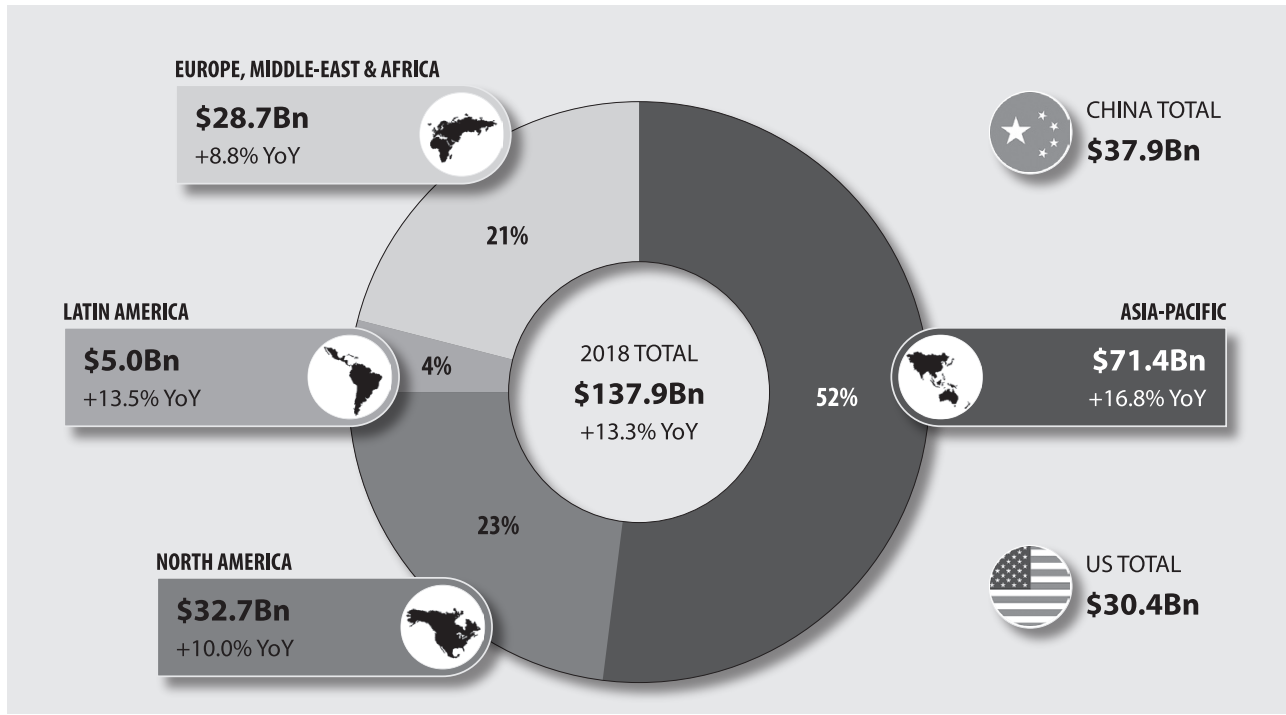

Source: https://newzoo.com/insights/articles/global-games-market-reaches-137-9-billion-in2018-mobile-games-take-half/. 
Among current trends in the video game industry, the year 2018 is the most stable year. According to a research company NewZoo, global gaming market revenue has been growing at double-digit rates since 2012, and the pace is expected to maintain at least until 2021.

Figure 2 shows Asia to be by far the largest market with $\$ 71$ billion in revenue in 2018 alone, followed by North America and Europe (including the Middle East and Africa) with almost smaller revenue by double last year. ${ }^{1}$ Regionally, the three largest markets are the highest-income countries-China, the United States, and Japan (NewZoo, 2018: 16). The Japan's video game market continues to hold very high. It is ranked 3rd in the world's most valuable global markets with a growth of about $15.1 \%$ per year to about $\$ 19.2$ billion in $2018 .^{2}$

Due to the continued success of mobile gaming companies in Japan, the Japanese market is booming and its growth estimates changes twice a year. This means that their mobile gaming market is now almost the same size as for North America, with about a third of the number of the players. The Japanese players spend 1.5 more on games than consumers in North America, and even 2.5 times more than in Western Europe.

Just China alone will account for more than a quarter of all global gaming revenue, reaching $\$ 37.9$ billion this year. China continuously remains number one in the video game market according to its revenue and number of players. Mobile devices are the dominant force that generated $61 \%$ of the revenue in 2018, and projections are that by 2021 that revenue will have grown to $70 \%$ of the market. ${ }^{3}$

Overall, APAC (Asia and Pacific) have generated about $\$ 71$ billion, which is about $54 \%$ of total global gaming revenue. This represents an increase of about $17 \%$ annually. This area is a major initiator of further growth for the global video game industry, as the number of smartphone users in emerging markets such as India and Southeast Asia has been growing exponentially and at the same time the willingness to spend on mobile games is growing in already established markets such as China and Japan (NewZoo, 2018: 14-22).

North America is the second largest region with $\$ 32.7$ billion in revenue in 2018, showing an increase of about $10 \%$ in respect to the previous year. Most of this growth comes from playing on smartphones and to a lesser extent on consoles. In the EMEA region (Europe, Middle East and Africa), we see the same trends and earnings of about $\$ 28.7$ billion in 2018. In the European countries, mobile video game players are less willing to spend than the Americans, which accounts to about 1,6 times less

\footnotetext{
$1 \quad$ https://newzoo.com/insights/articles/global-games-market-reaches-137-9-billion-in-2018-mobilegames-take-half/

2 Ibid.

3 https://newzoo.com/insights/articles/global-games-market-reaches-137-9-billion-in-2018-mobilegames-take-half/
} 
than in North America. However, this is offset by the steady growth in the number of smartphone owners in the Middle East and Africa. Latin American video game revenue grew to $\$ 5$ billion in 2018 . ${ }^{4}$

The video game industry is the largest entertainment industry in the world today, even bigger than the music and film industries combined. Yes, music and films no longer have most of the pie in the entertainment industry, there has been a huge shift and the entertainment industry scene has a new ruler, which are video games. Figure 3 shows a graph displaying the ratios of the music, film and video game industries and their earnings.

Figure 3. Music, film, and video games markets

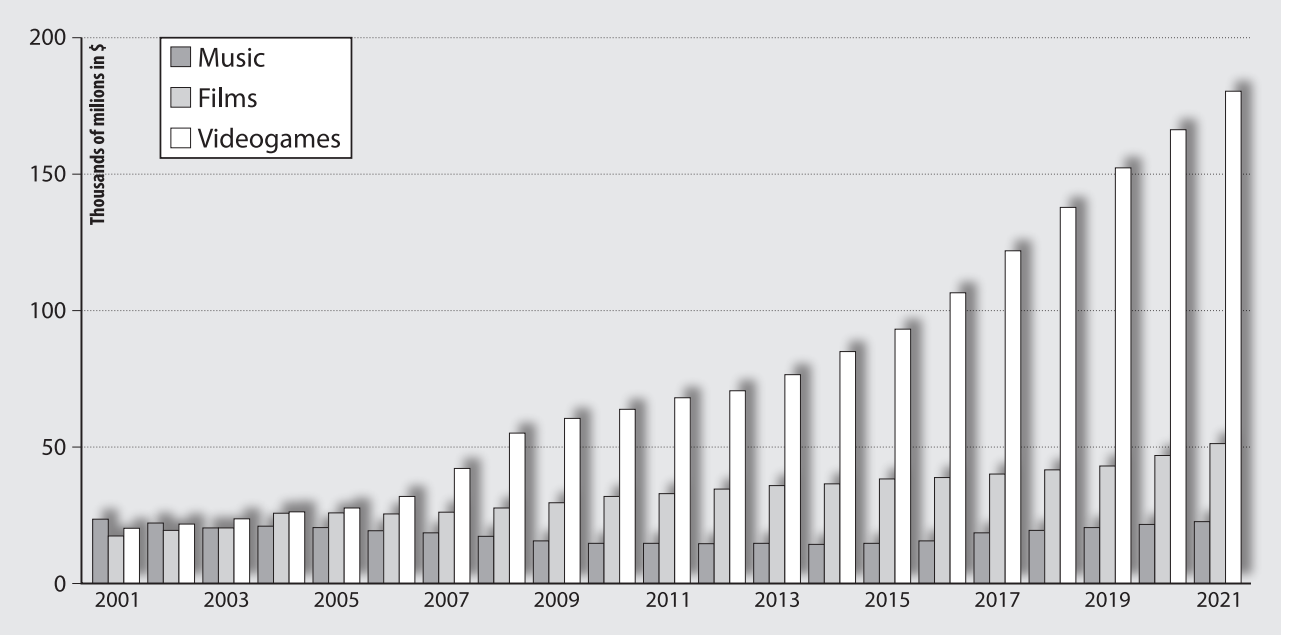

Source: https://lpesports.com/e-sports-news/the-video-games-industry-is-bigger-thanhollywood.

\section{Video game user demographics}

Although it is usually associated with teenagers, this industry has expanded to a diverse audience, producing games aimed at children, the elderly, and various interest groups. A research done by a company Earnest showed that younger people, especially those aged 18-24 years old, are more likely to buy video games than older people. Also, men tend to buy video games three times more than women. They also found that people earning more than $\$ 90,000$ were less likely to buy a video game, unlike their lower-income counterparts. The farther away people are from their college education, the less likely they are to buy video games.

$4 \quad$ Ibid. 
The demographic structure of video game users and consumers is best described through research statistics that are annually conducted in the United States by The Entertainment Software Association (ESA) and an analytics company NewZoo. Data shows that North America has a population of about 363,721,000 inhabitants and is comprised of the United States and Canada. From the total population, as many as $298,884,000$ are somehow connected to the Internet or have Internet access, which is as high as $81 \%$ of people. From that number, as many as $199,868,000$ play some form of video games, which accounts for over $54 \%$ of the total North American population. According to the ESA research, $60 \%$ of Americans play video games on a daily basis from which $41 \%$ is played on a personal computer, $36 \%$ on smartphones, while console players (PlayStation, Xbox...) rank third with 36\%. An average gamer is 34 years old, and an interesting fact is that $45 \%$ of all video game players in America are women (ESA, 2018: 6).

\subsection{Video games impacts on consumers}

Video games are fun for the large amount of people around the world. The technological advancement of this entertainment culture has challenged many consumers in different ways. According to many researches, video games can increase aggressive behavior, cause emotional outbursts, or even reduce inhibitions in many people. As a result of this increased exposure to this modern phenomenon, a larger number of research connects games to violent, aggressive and antisocial behavior. For this reason, various studies focus on exploring the impact of video games on society, that is consumers, to determine whether video games lead to aggressive, violent or antisocial behavior. This is another stereotype of the modern video game industry. The video game industry has grown tremendously through the evolution of modern consoles, games and other gaming accessories. Therefore, the "dust whirl” that surrounds this industry and video games makes some sense. Many consumers see video games as a necessity in life and not as an accessory. Due to this, the impact of video games has been the subject of many debates for years. There is no doubt that video games have a huge impact in society nowadays and on society itself, which is due to the growth of the video game industry, which in turn increases the impact of video games on society. Video games are considered to be attractive, tempting, and engaging activity that capture consumers' attention, arouse interests, and even in some cases lead to some level of addiction (Hainey, 2011: 240). They may be associated with a particular type of ,'professional" behavior such as better developed long-term and short-term memory, qualitative thinking, principled decision-making, and observation itself. Research conducted in the social sciences, with a topic related to aspects of video game playing, tends to link psychological attributes and/or cognitive and perceptual factors that influence players and their attitude (Banyte and Gadeikiene, 2015: 506). 


\subsection{Motivation, the backbone of the video game consumer profile}

Kesić (2006: 139) defines motivation as the state of an organism in which human energy is triggered and directed towards the state of things, most often towards an external goal, while he defines motives as the internal factors that trigger an activity while directing and managing it. The motivational component of the player, or the user, is a key element that can distinguish normal and excessive playing from problematic. Psychological needs and motivation to play can be dealing with some emotions such as loneliness, boredom, anger, isolation, various forms of frustration, it can also be a desire to have fun, escape from reality or meeting of one's own social needs. Motivation may also be the need for achievements, new challenges, the exercise of power, or the desire to control and raise self-esteem (Wan and Chiou, 2006: 762-766). There are also four types of needs for playing, such as having fun in free time, dealing with emotions, seeking of excitement, and escaping reality.

\subsection{Factors influencing the behavior of video game consumers}

Video games consumers (users) have been a growing part of our culture for a long time. Whether you are a hardcore gamer, or some casual user who plays a mobile game every once in a while, you are part of the gaming world. Over the years, this world has dealt with many stereotypes and false claims. One of the most damaging claims is made by the media condemning violence and other crimes as one of the influences of video games. It is shown that action video game players have better handeye coordination and visual motor skills, such as resistance to interference, sensitivity to information in their peripheral vision, and the ability to count assigned objects in a shorter time.

In his book Everything Bad Is Good for You, Steven Johnson argues that video games actually require a lot more from players than traditional games such as Monopoly. In order for the video game to be experienced, the user must first determine the goals, then know how to accomplish them, or execute them. Furtheremore, in order to achieve this, the user must know how different devices work from the hardware or software's point of view. Such skills are learned, and after a while become fundamental, but are taken for granted by many players. Playing video games requires strong analytical skills, flexibility and adaptability, and the process of learning the boundaries, goals, and controls of individual games is often very demanding and involves many cognitive functions. It is well known that most games require a lot of patience and focus from users, and contrary to the popular perception that games provide instant satisfaction, games actually delay pleasure for much longer than other forms of entertainment such as movies or even books. Some research even suggests that video games can increase the concentration and attention of players themselves (Green and Bavelier, 2003: 534). 


\section{Research methodology and the results}

The aim of this paper is to identify the main characteristics of users, or video game players, and to identify and determine user habits and trends that affect them. The subject of this research is to find out how many users, or consumers, play video games and generally how much are video games represented in our society. These trends "force" them to keep in touch with all the technology which is an unavoidable part of life today. It is also one of the goals to try to address all the misconceptions about typical video game users, and to show and prove that even the average consumer, a typical consumer, is not immune to the changes taking place in the technologically advanced 21 st century. An attempt will be made to determine what influence and impact video games have on consumers, what would be the advantages and disadvantages or positive effects, and what demographic structure prevails in the market itself. The aim of this research is to identify the main characteristics of users (consumers) who practice or play some form of video games on some of the devices such as personal computer, mobile phone (smartphone), game consoles or other similar devices. The second goal is to identify the users' gaming habits and how new trends affect those habits. Therefore, the focus of this research would be how many consumers use video games, or play them, and how many consumers are interested in any form of video games.

The research conducted for the purpose of this paper is based on three hypotheses, and they are as following:

- Hypothesis 1. Video games playing is reserved only for children.

- Hypothesis 2. Controlled video games playing can have positive effects on the person or user.

- Hypothesis 3. Playing video games is an escape from real-life problems.

\section{Research conclusion}

Three hypotheses were selected prior to the start of the research, and each of these hypotheses was related to several survey questions that would give an accurate answer to the hypothesis itself, which would accept or prove the hypothesis in question or refute it.

With this research and direct questions in the survey, the question about the users themselves and the video game market in general was to get answered, and these questions were designed to help fulfill the primary goal, which was to stimulate thinking about video games and how they affect us. Certainly, in order for the work to be rounded up into a meaningful whole, it was necessary to conduct research and collect users' responses and data. 
In each research it is necessary to bring out some basic demographic data about the respondents participating in it. Thus, 173 respondents participated in this research. Most of them were men (66,5\%), while the majority of the respondents -77 (44.5\%) were between the ages of 26 - 35. The most, as many as 99 (57,2\%) of the respondents are employed persons with an average monthly income between 3,000 and 6,000 kunas (29,5\%). According to the level of education, the majority of $42,2 \%$ have secondary education, while the number of household members is up to 4 in $35,8 \%$ of the respondents.

At the beginning of the paper, the first hypothesis was stated: „Video games playing is reserved only for children." This claim was attempted to be refuted by a survey questionnaire and research, that is by finding answers to questions that are directly related to that hypothesis. The survey questions, four of which were cited as a link to this hypothesis, showed that this hypothesis was incorrect. When the respondents were asked directly whether they agree with the statement: „Video games playing is reserved only for children," $97,1 \%$ (168 out of 173 respondents) said that they did not agree with this statement, and most of them, as many as $76,3 \%$, answered to the question: „Do you play video games (computer, console, mobile ...)?” positively. The majority of the respondents who participated in the survey are between $18-35$ years of age (includes the 2 largest groups of the respondents).

The second hypothesis states: „Controlled video games playing can have positive effects on the person or user." When asked how often do they play video games, most users answered every day, that is as many as $44,5 \%$. To the direct question whether playing video games within the normal limits has a positive effect on people in some way, $91,3 \%$ said yes. On the other hand, $86,7 \%$ of the respondents state that playing video games excessively can have a negative effect on people in some way. A majority, $52 \%$ of the respondents, said they had no difficulty limiting the time they spend playing video games. The vast majority, $71,1 \%$ of the respondents, said they disagree with the statement „I will miss a significant event in order to play video games.” These questions proved the Hypothesis 2. It was also proved that most the respondents are moderate in video game playing and that they think that moderate video game playing can have some positive effects on people. In addition, in their opinion, video games are not ahead of other life events and activities in their importance.

The third hypothesis states: "Playing video games is an escape from real-life problems." The reason why the respondents played video games the most was for fun and relaxation $(75,5 \%)$, while $12,1 \%$ responded that in such a way they escaped from everyday problems, while $9,2 \%$ said they played video games to become someone else even for a short moment and do something they couldn't in real life. Majority of the respondents fully agreed with the claim that they talk more with their friends than play video games $(49,7 \%)$, while $39,9 \%$ of the respondents disagree with the 
statement that imitating video game characters is cool. With these questions, or claims, we partially proved this hypothesis, as the respondents indicated that they play video games more for relaxation and fun, while the less common reason is that they escape from real-life problems. These questions also show that video games still cannot replace conversation with friends, because most people will still turn to a friend for advice and conversation to solve a problem, rather than to a video game purely for the sake of escaping the problem.

\section{Conclusion}

The development and advancement of information and telecommunications technologies has led to development of the entertainment industry, especially video games. The video game industry has grown into a global giant and is still advancing day by day. The video game market is huge and is facing many challenges of technological and marketing chracter. All people who own an electronic device, whether is it a computer, a mobile device, or some other device, are potential users, or consumers. Nowadays, almost every person has a mobile device and is therefore a potential part of the video game market itself and an ideal candidate for any video game manufacturer and marketer. The video game market is one of the most profitable in its segment, already exceeding the film and music industry. But video games are successful because manufacturers have mastered key concepts that keep players in the game. They know exactly how to connect and keep them in the game. The current consumers enjoy an exciting world of interactivity and fun at their fingertips.

From playing online video games to board games on your tablets and smartphones, players spend more time playing today than ever before. Even with so many options and devices available to choose from, players want more consistency and continuity as they change the platforms when playing video games. The video game industry is one of the most advanced economic sectors in the world, it implies everything from developing video games to finding the right marketing solutions for their sales. Although from a user's perspective, video games, as the end product of this industry, are primarily intended for fun and entertainment. Nowadays, they have greater and wider use, and their presence on social networks makes them an excellent marketing tool for launching and selling of various products, and even mobile phone manufacturers integrate them into their devices and use them to better sell their devices. The purpose of this paper was to show and prove the popularity of video games in general society, to outline trends, and to show the impact that video games have on the lives of a modern man.

Video games are no longer only associated with children, but with different ages and even older people. New trends are emerging, new technologies, and even new 
sports that are breathtaking to the masses of people around the world. It can be said that technology is irreversibly changing our world and society as we know it. Behind the video game market are figures that confirm each fact and thesis presented in this paper, and it has been proved by our own research. The demographic structure of video game consumers is changing dramatically, technology dictates new trends, while we are forced to change habits if we want to keep up. Video games are changing the awareness and behavior of consumers, who are becoming more attractive to marketers and adaptable to new market changes. Video games are no longer what they used to be. Simply, video games today are an unavoidable aspect of every human being and society as a whole, and it is very important to adapt to them and accept them. Video games are no longer reserved only for children and are no longer considered to be an escape from life's problems. On contrary, they are considered to be a good form of entertainment, relaxation, and in some cases, professional orientation, or work. This extremely demanding industry and its markets are currently highly prone to changes, due to their accelerated growth and advancement of technologies, and it is essential that marketers as well as the users, or consumers can adapt and accept any changes.

\section{Literature}

1. Banyte, J. and Gadeikiene, A. 2015. The effect of consumer motivation to play games on video game-playing engagement. Procedia Economics and Finance, 26: 505-514.

2. Bareta, Ž. 2013. Savremena industrija videoigara.

3. https://singipedia.singidunum.ac.rs/izdanje/41465-savremena-industrija-video-igara (retrieved on 6. 1. 2019)

4. Bidžos, A. 2017. Utjecaj videoigara na razvoj djeteta. Završni rad. Pula: Sveučilište Jurja Dobrile u Puli.

5. Bilić, V., Gjukić, D. i Kirinić, G. 2010. Mogući učinci igranja računalnih igrica i videoigara na djecu i adolescente. Napredak: časopis za interdisciplinarna istraživanja u odgoju i obrazovanju, 151 (2): 195-213.

6. BITKRAFT: A Deep Dive Into the World of Competitive Video Games. 2017.

7. https://esportsobserver.com/wp-content/uploads/2017/01/Esports_101-whitepaper-BITKRAFT.pdf (retrieved on 27. 1. 2019)

8. Ching Yi Ngai, A. 2005. Cultural influences on video games.

9. https:/www.collectionscanada.gc.ca/obj/s4/f2/dsk3/OWTU/TC-OWTU-638.pdf (retrieved on 5. 1. 2019)

10. Egenfeldt-Nielsen, S., Smith, J. H. and Pajares Tosca, S. 2008. Understanding video games - the essential introduction. https://is.muni.cz/el/1421/podzim2016/IM082/Simon_Egenfeldt-Nielson__Jonas_Heide_Smith__Susana_Pajares_Tosca_Understanding_Video_ Games_The_Essential_Introduction_2008.pdf (retrieved on 20. 12. 2018)

11. ESA. 2018. Essential facts about the computer and video game industry.

12. http://www.theesa.com/wp-content/uploads/2018/05/EF2018_FINAL.pdf (retrieved on 10. 1. 2019) 
13. Esports, N. 2017. The Esports Playbook - Maximizing your investment through understanding the fans. The Nielsen Company.

14. Esposito, N. 2005. A Short and Simple Definition of What a Videogame Is. http://www. utc.fr/ nesposit/publications/esposito2005definition.pdf (retrieved on 20. 12. 2018)

15. Franić, Š. 2016. Strateški menadžment u industriji računalnih igara na primjeru poduzeća Activision Blizzard. Završni rad. Sveučilište u Splitu, Ekonomski fakultet.

16. Fu, K., Hainey, T., Baxter, G. and İnal, Y. 2016. A Study of the Motivations for Playing Computer Games at Secondary Education Level in Turkey: The Potential for GamesBased Learning. https://www.researchgate.net/publication/318094750_A_Study_of_ the_Motivations_for_Playing_Computer_Games_at_Secondary_Education_Level_in_ Turkey_The_Potential_for_Games-Based_Learning (retrieved on 29. 12. 2018)

17. Granic, I., Lobel, A. and Engels, R. 2014. The Benefits of Playing Video Games. American Psychologist, 69 (1): 66 -78.

18. Grbac, B. and Lončarić, D. 2010. Ponašanje potrošača na tržištu krajnje i poslovne potrošnje. Rijeka.

19. Grbac, B. and Meler, M. 2007. Marketinško planiranje - preduvjet uspješnog razvoja. Zagreb.

20. Green, S. and Bavelier, D. 2003. Action video game modifies visual selective attention. Nature, 423 (6939): 534-7.

21. Gutić, D. and Barbir, V. 2009. Ponašanje potrošača. Makarska.

22. Haagsma, M., Pieterse, M., Peters, O. and King, D. L. 2013. How Gaming May Mecome a Problem: A Qualitative Analysis of the Role of Gaming Related Experiences and Cognitions in the Development of Problematic Game Behavior. International Journal of Mental Health and Addiction, 11 (4).

23. Hamari, J. 2016. What is eSports and why do people watch it? https://www.emeraldinsight.com/doi/pdfplus/10.1108/IntR-04-2016-0085 (retrieved on 27. 1. 2019)

24. Kesić, T. 2006. Ponašanje potrošača. Zagreb.

25. Kotler, P., Wong, V., Saunders, J. and Armstrong, G. 2006. Osnove marketinga. Zagreb.

26. Lozić, J. 2018. Trendovi u industriji zabave $i$ videoigrica. https://hrcak.srce.hr/209285 (retrieved on 20. 1.2019)

27. Nakić, S. 2014. Područja primjene stavova potrošača. Zagreb.

28. NewZoo. 2018. 2018 global games market report. https://cdn2.hubspot.net/hubfs/700740/ Reports/Newzoo_2018_Global_Games_Market_Report_Light.pdf (retrieved on 6. 1. 2019)

29. Rakas-Drljan, A. and Mašić, I. 2013. Navike učenja i stavovi prema učenju.

30. https://hrcak.srce.hr/138820 (retrieved on 15. 1. 2019)

31. Schiffman, L. G. and Kanuk, L. L. 2004. Ponašanje potrošača. Zagreb.

32. Shaw, A. 2010. What Is Video Game Culture? Cultural Studies and Game Studies.

33. http://citeseerx.ist.psu.edu/viewdoc/download?doi=10.1.1.863.6217\&rep=rep1\&type=pdf (retrieved on 20.12.2018)

34. Turčinov, S. 2017. Bibliografska i sadržajna obrada videoigara. Zadar. https://repozitorij. unizd.hr/islandora/object/unizd\%3A1658/datastream/PDF/view (retrieved on 20. 12. 2018)

35. Varga, D. 2018. Neka obilježja igranja računalnih igrica.

36. https://zir.nsk.hr/islandora/object/ffos\%3A4213/datastream/PDF/view (retrieved on 26. 1. 2019)

37. Wan, C. i Chiou, W. 2006. Why are adolescents addicted to online gaming? 
38. https://www.liebertpub.com/doi/10.1089/cpb.2006.9.762 (retrieved on 3. 1. 2019)

39. Winget, M. 2011. Videogame Preservation and Massively Multiplayer Online Role-Playing Games: A Review of the Literature. Journal of the American Society for Information Science \& Technology, 62 (10): 1869-1883.

40. https://www.researchgate.net/profile/Megan_Winget/publication/220433738_Videogame_Preservation_and_Ma ssively_Multiplayer_Online_RolePlaying_Games_A_Review_of_the_Literature/links/55356ca80cf218056e9297d7.pdf (retrieved on 23. 12. 2018)

\section{Internet sources}

41. https://repozitorij.unipu.hr/islandora/object/unipu:1662/preview (retrieved on 21. 12. 2018)

42. https://www.ama.org/ (retrieved on 18. 12. 2018)

43. https://newzoo.com/insights/articles/global-games-market-reaches-137-9-billion-in2018-mobile-games-take-half/ (retrieved on 8. 1. 2019)

44. https://lpesports.com/e-sports-news/the-video-games-industry-is-bigger-than-hollywood (retrieved on 8. 1. 2019)

45. https://gamerant.com/gamer-loner-stereotype-study-video/ (retrieved on 5. 1. 2019)

46. https://www.earnest.com/blog/the-demographics-of-video-gaming/ (retrieved on 5. 1. 2019)

47. https://www.netokracija.com/istrazivanje-o-gamerima-u-hrvatskoj-147345 (retrieved on 12.1.2019)

48. https://www.statista.com/statistics/748044/number-video-gamers-world/ (retrieved on 22. 1. 2019)

49. http://www.clairfield.com/wp-content/uploads/2017/02/Gaming-Industry-and-Market-Report-2018.01-2.pdf (retrieved on 22. 1. 2019)

50. https://dmarket.com/blog/gaming-trends-2018/ (retrieved on 20. 1. 2019)

51. https://core.ac.uk/download/pdf/82392245.pdf (retrieved on 27. 12. 2018)

52. https://en.wikipedia.org/wiki/Video_game\#Behavioral_effects (retrieved on 15. 1. 2019)

53. https://web.archive.org/web/20060329174957/http://www.bcs.rochester.edu/people/ daphne/GreenandBavelier.pdf (retrieved on 20. 1. 2019)

54. https://www.newswise.com//articles/view/543366/ (retrieved on 23. 1. 2019)

55. https://www.forbes.com/sites/kevinanderton/2018/06/25/the-impact-of-gaming-a-benefit-to-society-infographic/\#529ed7f4269d (retrieved on 26. 1. 2019)

56. https://www.limelight.com/resources/white-paper/state-of-online-gaming-2018/ (retrieved on 27. 1. 2019)

57. https://newzoo.com/insights/articles/male-and-female-gamers-how-their-similaritiesand-differences-shape-the-games-market/ (retrieved on 23. 1. 2019)

58. https://www.apa.org/pubs/journals/releases/amp-a0034857.pdf (retrieved on 24. 1. 2019)

59. https://en.wikipedia.org/wiki/Esports (retrieved on 27. 1. 2019)

60. https://newzoo.com/ (retrieved on 28. 1. 2019)

61. https://www.bbc.co.uk/newsround/37773832 (retrieved on 28. 1. 2019)

62. https://www.statista.com/statistics/490522/global-esports-market-revenue/ (retrieved on 28. 1. 2019)

63. https://newzoo.com/insights/articles/newzoo-global-esports-economy-will-reach-9056-million-2018-brand-investment-grows-48/ (retrieved on 29. 1. 2019) 
64. http://www.mindshareintheloop.com/home/2016/06/14/game-on-what-marketersshould-know-about-esports-fans/ (retrieved on 29. 1. 2019)

65. https://www.nielsen.com/content/dam/nielsenglobal/ru/docs/nielsen-esports-playbook. pdf (retrieved on 25. 1. 2019)

66. https://variety.com/2018/digital/news/esports-video-games-olympics-1202709110/ (retrieved on 27. 1. 2019)

67. https://www.iab.com/wp-content/uploads/2018/05/IAB_Esports_Marketers_ Guide_2018-05_Final.pdf (retrived on 29. 1. 2019)

68. https://www.valuewalk.com/2018/04/esports-v-sports-future-sport-online/ (retrieved on 29. 1. 2019)

69. https://www.redbull.com/gb-en/dota-international-prize-pool-vs-real-sports (retrieved on 30.1.2019)

\section{8}

\section{Profili potrošača videoigara}

\section{Sažetak}

Put razvoja videoigara ispunjen je drastičnim promjenama. Rast i jačanje tehnologija i porast inovacija u tehnološkom sektoru neminovno su doveli do jačanja i rasta te industrije koja danas postiže neočekivane, zavidne rezultate. Osnovna ljudska potreba za zabavom i druženjem pridonosi popularnosti videoigara. Danas videoigre igraju ljudi svih uzrasta i spolova, a najčešći razlozi igranja videoigara su zabava, druženje, učenje i rješavanje stresa, no videoigre omogućuju i interaktivnu zabavu, za razliku od knjige, filma ili predstave. Popularnosti videoigara svjedoče brojne zajednice na društvenim mrežama putem kojih profesionalni igrači dijele svoja iskustva, savjete te recenzije videoigara, a tu su i statistike koje potkrepljuju tu popularnost i rast. Mogućnosti koje nudi industrija videoigara nije potrebno naročito naglašavati jer rezultati, statistike i oduševljeni igrači govore sami za sebe. Ovaj se rad bavi ponašanjem potrošača koji igraju videoigre. Cilj je utvrditi glavna obilježja korisnika, tj. igrača videoigara te prepoznati i odrediti navike korisnika i trendove koji utječu na korisnike. Potrošač je društveno i kulturno biće. On je u isto vrijeme individua za sebe, član obitelji, pripadnik grupe ili određene društvene klase ili sloja, predstavnik određene nacije, rase, vjere, državljanin određene zemlje i drugo. Potrošač je osoba koja posjeduje novac (sredstva) i volju za kupovinom proizvoda i usluga. U ovome radu, te definicije potrošača stavit će se u korelaciju s tržištem videoigara, s industrijom koja obuhvaća različite oblike moderne zabave. Pokazuje se da su tehnologija i novi načini zabave prisutni među svima te da se potrebno prilagoditi vremenu u kojem živimo. Igranje nekog oblika videoigara postala je normalna aktivnost svakog normalnog modernog pojedinca.

Ključne riječi: ponašanje potrošača, videoigre, gamer, gaming, influencer, marketing, društvene mreže, esport, tržište, industrija, korisnik, igrač 